\title{
Economic Growth and Carbon Dioxide Emissions in East African Countries: A Pooled Mean Group Approach
}

\author{
Ghirmai Tesfamariam Teame*, Amine Teclay Habte \\ Department of Economics and Finance, College of Business and Social Sciences, Adi-Keih, Eritrea \\ Email address: \\ santarosaye@gmail.com (G. T. Teame), amineth2020@gmail.com (A. T. Habte) \\ ${ }^{*}$ Corresponding author
}

\section{To cite this article:}

Ghirmai Tesfamariam Teame, Amine Teclay Habte. Economic Growth and Carbon Dioxide Emissions in East African Countries: A Pooled Mean Group Approach. International Journal of Business and Economics Research. Vol. 9, No. 4, 2020, pp. 160-169.

doi: 10.11648/j.ijber.20200904.11

Received: May 8, 2020; Accepted: May 25, 2020; Published: June 3, 2020

\begin{abstract}
In recent years, due to factors such as increases in greenhouse gas (GHG) and carbon dioxide $\left(\mathrm{CO}_{2}\right)$ emissions, global warming and climate changes has become a major threat for all countries. However, contrary to the deep-seated belief that human impact on the environment is negative and progressive, recent empirical research shows that certain types of pollutants follow an inverted-U shape or Environmental Kuznets curve (EKC), as income grows. The EKC hypothesis postulates that environmental degradation (pollution) increases up to a certain level, as income goes up; after that, it decreases. Thus, using the EKC hypothesis as a theoretical framework and applying Pooled Mean Group (PMG) approach, this paper examines the nexus between $\mathrm{CO}_{2}$ emissions, economic growth, Foreign Direct Investment (FDI) and total population. The study uses panel data of 12 East African countries over the period 1981-2016. Our empirical result shows that there exists a monotonically increasing relationship between $\mathrm{CO}_{2}$ emissions and economic growth both in the short-run and long-run, contrary to what is claimed by the EKC hypothesis. Moreover, per capita $\mathrm{CO}_{2}$ emissions increase positively with respect to FDI and total population in the long-run. The result of the study also reports the existence of unidirectional causalities running from per capita GDP, FDI and total population to per capita $\mathrm{CO}_{2}$ emissions in the long-run, while unidirectional short-run causalities was observed from GDP and FDI to $\mathrm{CO}_{2}$ emissions, without any feedback effects. Therefore, these unidirectional causalities imply that $\mathrm{CO}_{2}$ emission reduction or abatement measures can be implemented without having any adverse effect on the real output growth or economic growth, in East Africa.
\end{abstract}

Keywords: Economic Growth, $\mathrm{CO}_{2}$ Emissions, Pooled Mean Group, Environmental Kuznets Curve, Causality, East Africa

\section{Introduction}

There is a deep-seated belief that human impact on the environment is both negative and progressive. Consequently, as the result of their actions, humans have faced poor environmental conditions, which is manifested in the form of global warming and climate change. Recently, these have been posing increasing and unprecedented threats to the world economies and humans. In reality, what we think of as environmental problems become more apparent and even get worse with economic development, population growth, industrialization, and urbanization. These problems become even more serious in developing countries, as they have to make a tough trade-off decision between economic growth and environmental protection [1]. In their vigorous pursuit to achieve the desired level of economic growth and development and to maintain at this level, developing countries have kept environmental considerations for granted or at least as a secondary objective in their policy considerations. This has led to serious environmental degradations and threatened their sustainable future $[2,3]$.

Due to the mounting public concern over the quality of the environment and ostensible massive GHG emissions, the worldwide organizations such as the United Nations have been attempting to reduce the adverse impacts of global warming through intergovernmental and binding agreements. Moreover, the nature of the relationship between the level of economic activity or income and environmental quality indicators has been a subject of large debate in the economic literature for many years. Experts have been trying to explain the relationship 
between economic growth and environmental pollution (environmental quality indicators) using the EKC hypothesis, which proposes an inverted U-shaped relationship between economic growth and an environmental quality indicator. According to the EKC hypothesis, environmental quality suffers during early stages of economic development, but this trend improves in the later stages, when a certain level of income is achieved. The EKC indicates the growth trajectory that should be followed in order to achieve the desired target in environmental quality. Thus, the EKC hypothesis claims that pollution is only a transitional phenomenon in the course of economic growth, and there is no conflict between economic growth and environmental degradation in the long-run, because the only way to escape from environmental degradation, which resulted from economic growth, is to grow further and become rich.

The International Panel on Climate Change (IPCC) fourth assessment report shows that the long observed trend in declining global $\mathrm{CO}_{2}$ emissions intensity per unit of GDP has reversed around the year 2000 [4]. This means that global $\mathrm{CO}_{2}$ emissions are growing faster than at any time since 1970 [5]. Amongst several environmental pollutants causing climate change, $\mathrm{CO}_{2}$ is held responsible for as much as $58.8 \%$ of the total GHG emissions, globally. Many scientists have argued that increasing levels of $\mathrm{CO}_{2}$ emissions significantly contribute to the warming of global temperatures and climactic instability. Since the growth in $\mathrm{CO}_{2}$ emissions is attributable to a rapid surge in economic activities, identifying the relationship between $\mathrm{CO}_{2}$ emissions and economic growth has important implications for appropriate joint economic and environmental policies. The relationships between economic growth and $\mathrm{CO}_{2}$ emissions have been intensively analyzed empirically over the past three decades, and most of the studies focus on testing the validity of the EKC hypothesis.

East Africa appears to be an interesting case study, because it is one of the fastest growing regions in Africa, along with an alarming level of environmental pollutions. For example, eight of the countries in East Africa are responsible for about 1.43 per cent of the global emissions of $\mathrm{CO}_{2}$. On a per capita basis, the region's emissions are 2.5 times below the world average. However, in all East African countries, $\mathrm{CO}_{2}$ emissions relative to GDP are very high, ranging from 1.5 to 37.5 times of the world average. These results in the high regional GDP carbon intensity, which for East Africa is eight times the world average [6]. Therefore, taking East Africa's position in the global $\mathrm{CO}_{2}$ emissions, and the negative consequences of $\mathrm{CO}_{2}$ emissions on the health of individuals and plants as well as the economy into considerations, it is highly imperative to examine the nature of its long-run relationship with economic growth. Moreover, examining the direction of the causal relationship between economic growth and $\mathrm{CO}_{2}$ emissions helps in articulating comprehensive economic policies on economic growth and on designing emission reduction or abatement measures.

Against this backdrop, the objective of the study is twofold. First, it attempts to determine the relationship between the economic growth and $\mathrm{CO}_{2}$ emissions, during 1981-2016 in 12 East African countries. For this purpose, PMG analysis is employed based on the EKC hypothesis. Second, it aims to examine the direction of causal relationship between economic growth and $\mathrm{CO}_{2}$ emissions following Granger causality test. Therefore, the rest of the paper is organized as follows. In Section 2, we present the genesis of the EKC hypothesis and review of the available literature. Section 3 presents model specification. Source of the data and their description is presented in section 4 . Section 5 covers the empirical results. Finally, conclusions and policy recommendations are presented in section 6 .

\section{Literature Review}

The 1971 Nobel Prize winner, Simon Kuznets, has foreseen that there exists a changing relationship between per capita income and income inequality. He observed that as per capita income increases, income inequality tends to increases at first and then starts declining after a turning point is reached [7]. This inverted U-shaped or a bell-shaped relationship is known as the Kuznets Curve.

In the 1990s and onwards, the Kuznets curve took on a new path after a similar inverted U-shaped relationship is found between per capita income and environmental degradation, as does income inequality and per capita income in the original Kuznets Curve $[8,9]$. The studies that examine the relationship between environmental quality and economic growth has begun with three working papers. These are the National Bureau of Economic Research working paper as part of a study of the environmental impacts of NAFTA [10]; World Development Report of the World Bank 1992 [11]; and a development discussion paper as part of a study for the International Labor Organization [12]. Though, Grossman and Krueger (1991) was the first to point out an inverted-U relationship between pollutants $\left(\mathrm{SO}_{2}\right.$ and smoke) and per capita income, the Kuznets' name was attached to the inverted$\mathrm{U}$ relationship between the environmental quality and economic growth later, and Panayotou (1993) was first to coin it as the EKC $[13,14]$. Ever since, the EKC hypothesis has become an independent research issue, which has provoked a large body of theoretical and empirical research [1].

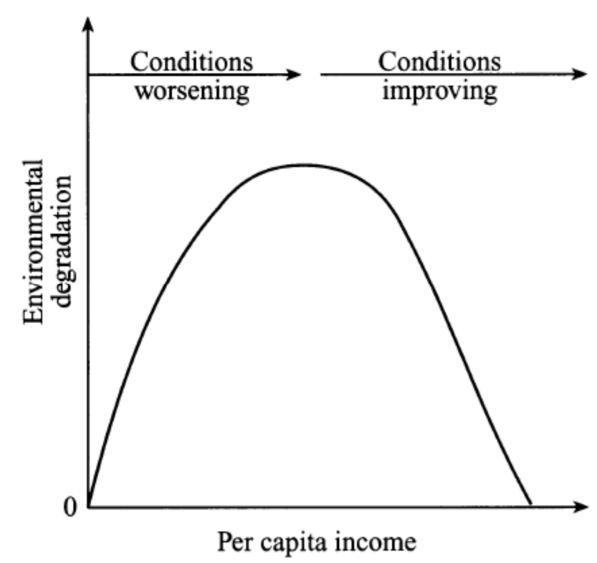

Figure 1. A schematic representation of an EKC. 
A simple schematic model of an environmental Kuznets curve is presented in figure 1 where the horizontal axis represents per capita income, while an indicator of environmental degradation is given on the vertical axis.

Many theoretical and empirical studies have come up in the process of attempting to explain the nature of the relationship between economic growth and different measures of environmental quality indicators, especially $\mathrm{CO}_{2}$ emissions. Thus, in this section, an attempt is made to blot some of the studies that have supported and those that have not supported the EKC hypothesis, as well as report of causality tests for different environmental quality indicators, using panel data.

\subsection{Studies Supporting the EKC Hypothesis}

In this section, we present several empirical studies which have confirmed the existence of an EKC relationship between different measures of environmental quality indicators and economic growth, using panel data. For example, the seminal work of Grossman and Krueger (1991) has investigated the relationship between economic growth and measures of air quality in terms of emissions of Sulphur dioxide $\left(\mathrm{SO}_{2}\right)$, dark matter and suspended particulate matter (SPM) in a cross-section of urban areas located in 42 countries during 1977-88. Their study has reported that $\mathrm{SO}_{2}$ and smoke follows the EKC hypothesis. Another early study has also examined the EKCs for 10 different indicators of environmental pollutants using data from 149 countries during 1960-1990, and reported that only two of them (ambient levels of SPM and ambient $\mathrm{SO}_{2}$ ) has followed the EKC hypothesis [11]. Reference [12] has also confirmed the existence an EKC hypothesis for $\mathrm{SO}_{2}, \mathrm{NOx}, \mathrm{SPM}$, and deforestation. Using almost the same indicators, except replacing $\mathrm{CO}$ for deforestation and data from 30 high, middle and low-income countries for the period 1973 to 1984 , an inverted U-shape patterns for $\mathrm{SO}_{2}, \mathrm{NOx}$ and SPM emissions against income, is reported [15]. Similarly, from a panel of 28 EU countries observed between 1990 and 2014, and applying pooled OLS and fixed effect models an EKC hypothesis is supported for emissions of Sulphur oxides and non-methane volatile organic compounds [16]. Reference [17] has used cross-country panel datasets of OECD countries, and examined the relationship between per capita income and a wide range of environmental indicators. The study has consistently found significant relationships between income and all examined environmental indicators, but reported an inverted-U relationship only for local air pollutants namely: $\mathrm{SO}_{2}$, SPM, and fecal coliform, whilst indicators with more global or indirect impacts have either increased monotonically with income or else. Finally, using data from 149 countries during the period 1960-1990, and applying OLS method, the EKC hypothesis is confirmed for the case of $\mathrm{SO}_{2}$ and the SPM pollutants, but not for carbon emissions per capita and deforestation [18].

With the advancement of statistical computation techniques, researchers have investigated the existence of an EKC like relationship for different pollutants using panel cointegration techniques, simultaneous equation techniques, fixed or random effect models, Dynamic OLS (DOLS), Fully Modified OLS (FMOLS), panel smooth transition regression, Vector Error Correction Model (VECM), Autoregressive Distributed Lag (ARDL) model, PMG and others. In addition to this, they have examined the causal relationship among the variables using Granger causality test. Here, we will present studies that have confirmed the EKC hypothesis as well as provided causal relationship for $\mathrm{CO}_{2}$ emissions only. Reference [19], for example, has used panel error correction model (ECM) for data from 15 new EU members during 1992-2010. The result of the study has reported a finding that supports the EKC hypothesis. Moreover, it has reported unidirectional short-run causality running from energy consumption, trade openness and urbanization to $\mathrm{CO}_{2}$ emissions. Similarly, applying Pedroni panel cointegration test and Granger panel VECM, for data from 15 Middle East and North African (MENA) countries during 1975-2007, an EKC hypothesis is validated for all oil-exporting countries [20]. Moreover, using simultaneous-equation models for data from 14 MENA countries over the period 1990-2011; and using panel unit root and cointegration tests for data from 12 MENA countries during 1981-2005 an inverted-U relationship and bidirectional causal relationships between economic growth and $\mathrm{CO}_{2}$ emissions and energy consumption and $\mathrm{CO}_{2}$ emissions is reported [21, 22]. Another study, using FMOLS and VECM Granger causality test, and data from 18 Latin American and Caribbean countries during 1980-2010, has supported the EKC hypothesis and reported a bidirectional causality between $\mathrm{CO}_{2}$ and all the variables which are included in the study [23]. Reference [24] has also applied an ARDL and VECM technique for data from five Association of Southeast Asian Nations (ASEAN) countries for the period 1971-2009 and reported an EKC hypothesis for two countries and a bidirectional Granger causality between energy consumption and $\mathrm{CO}_{2}$ emissions in all the five ASEAN countries. The EKC hypothesis is also confirmed for the same countries, but using panel smooth transition regressions for the period during 1980-2008 [25]. Finally, using panel cointegration technique for data from the five ASEAN countries during 1980-2006, EKC hypothesis and unidirectional causal relationship running from $\mathrm{CO}_{2}$ emissions to energy consumption is reported [26].

\subsection{Studies That Do Not Support the EKC Hypothesis}

On the other hand, using cross-countries panel data, some studies have asserted that there is no evidence to support the EKC hypothesis, and they rather reported monotonically increasing or decreasing, N-shaped and U-shaped relationship between various indicators of environmental qualities and per capita income. Reference [11], for example, has reported a monotonically increasing relationship between per capita carbon emissions and income. Similarly, in an analysis of international variations of atmospheric pollution variables in around 1000 locations worldwide, $\mathrm{SO}_{2}$ and smoke have an N-shaped relationship with income [27]. Reference [28] has also asserted that $\mathrm{SO}_{2}$ emissions declines 
while $\mathrm{NOx}$ and $\mathrm{CO}_{2}$ emissions increase with per capita income. Moreover, two separate studies that have used a set of city-specific panel data in China and panel data from Turkish provinces have reported $\mathrm{N}$-shaped curves for $\mathrm{SO}_{2}$ emissions against income [29, 30]. According to these findings, economic growth does not clearly solve the problems of air pollution or environmental degradations in general.

Focusing on the studies that have only dealt with $\mathrm{CO}_{2}$ emissions, we can see that using panel smooth transition regressions, no evidence of EKC is reported for 77 nonOECD countries during the period 1971-1997 [31]. Similarly, using data from 106 countries and employing panel VAR technique for the period during 1971-2011, there was no evidence to support the EKC hypothesis [32]. References [33-35] have used data from 130 countries during 1951-1986, from 19 Asian countries during 1950-2009, and from 36 nations during 1973-1997, respectively, and have reported either a monotonically rising or no relationship between $\mathrm{CO}_{2}$ emissions and income. Moreover, applying DOLS, FMOLS, dynamic fixed effect and panel Granger causality test to data from six Gulf Cooperation Council (GCC) countries, a monotonically increasing long-run relationship and a bidirectional causality between $\mathrm{CO}_{2}$ emissions and economic growth is reported [36]. The following two studies, have used panel cointegration test and panel VECM for data from three North African countries during 1980-2012 and 15 MENA countries during 1973-2008, respectively, and have not supported the EKC hypothesis and reported a unidirectional causal relationship running from economic growth to $\mathrm{CO}_{2}$ emissions [37, 38]. Reference [39] has used PMG approach for 12 East African countries for the period from 1990 to 2013 and reported a U-shaped long-run relationship between per capita income and $\mathrm{CO}_{2}$ emissions. Finally, using data from 31 developing countries and applying dynamic panel threshold framework, no evidence can be provided to support either the EKC hypothesis or causal relationship between $\mathrm{CO}_{2}$ emission and economic growth [40].

\section{The Empirical Model}

The reduced form of the empirical model of the EKC hypothesis, which is adopted for the study, is given by:

$$
C O_{2 i, t}=f\left(G D P_{i, t}, F D I_{i, t}, \text { Pop }_{i, t}, u_{i, t}\right)
$$

Where; $\mathrm{CO}_{2 i, t}$ is per capita carbon dioxide emissions in metric tons in country $i$ at time $t, G D P_{i, t}$ is per capita income of country $i$ at time $t, F D I_{i, t}$ is foreign direct investment in country $i$ at time $t, \operatorname{Pop}_{i, t}$ is total population in country $i$ at time $t$, and $u_{i, t}$ is the standard random error term.

To examine the possible form of relationships between levels of pollution and income, many researchers have followed the standard quadratic specification of the EKC hypothesis (2) [41]. Thus, our study follows this quadratic specification of the EKC model. Moreover, all the variables in our model are specified in log-linear form, because it is noted that log-linear specification provides more appropriate and efficient results as compared to simple linear functional form of the model. Furthermore, using values of all variables in their natural logarithmic $(l n)$ form helps to reduce heteroscedasticity and to obtain the elasticity of the relevant variables.

$$
\begin{aligned}
& \ln C O_{2 i, t}=\beta_{0}+\beta_{1}\left(\ln G D P_{i, t}\right)+\beta_{2}\left(\ln G D P_{i, t}\right)^{2}+\beta_{3}\left(\ln F D I_{i, t}\right)+ \\
& \beta_{4}\left(\ln P o p_{i, t}\right)+u_{i, t}
\end{aligned}
$$

The existence of an inverted U-shaped like relationship between $\mathrm{CO}_{2}$ emissions and economic growth depends on getting a positive sign of $\beta_{1}$ and a negative sign of $\beta_{2}$ coefficients in (2). In line with the objectives of our study, the long-run relationship between the variables is estimated using PMG approach, while the causal relationships between the variables are estimated using Granger panel causality test.

\subsection{Model Specification}

Due to its numerous attractive features over the other alternative models, our study applies the recently developed PMG/ARDL approach, which is becoming increasingly popular in the empirical research. PMG estimation approach assumes that the parameters are heterogeneous across groups [39]. The PMG estimator combines pooling and averaging of coefficients. Moreover, it is considered that the analyzed economies differ in their economic policy [42].

The ARDL $(p, q, q \ldots q)^{1}$ representation of (2), which is used to estimate a long-run cointegrating relationship among the variables, is given by (3) [42]. ARDL models are standard least squares regressions that include lags of both the dependent variable and independent variables as regressors.

$$
\ln C O_{2 i, t}=a_{i}+\sum_{k=1}^{p} b_{i k} \ln C O_{2 i, t-k}+\sum_{k=0}^{q} c_{i k}^{\prime} \ln x_{i, t-k}+u_{i, t}
$$

Where $x_{i, t}$ is a vector of explanatory variables, $a_{i}$ represent the fixed effects, the coefficient of the lagged dependent variables, $b_{i k}$, are scalars, and $c^{\prime}{ }_{i k}$ are coefficient vectors. It is convenient to work with the following re-parametrization, which converts (3) into an Unrestricted Error Correction Model (UECM) (4).

$$
\begin{aligned}
& \Delta \ln C O_{2 i, t}=a_{i}+\sum_{k=1}^{p-1} b_{i k} \Delta \ln C O_{2 i, t-k}+\sum_{k=0}^{q-1} c_{i k}^{\prime} \Delta \ln x_{i, t-k}+ \\
& d_{i} \ln C O_{2 i, t-1}+e_{i}^{\prime} \ln x_{i, t}+u_{i, t}
\end{aligned}
$$

Where in (4), $b_{i k}$ and $c^{\prime}{ }_{i k}$ represent the short-run coefficients (error correction dynamics) of lagged dependent and independent variables, respectively, while $d_{i}$ and $e_{i}^{\prime}$ correspond to the long-run relationships. Moreover, $a$ and $u_{i, t}$ are country-specific intercept and white noise, respectively and $\Delta$ refers to the first difference operator.

In an attempt to examine the validity of the EKC hypothesis, we have examined the behavior of the long-run relationship between $\mathrm{CO}_{2}$ emissions and the regressors (ln

$1 p, q$ represent to the number of lags corresponding to the dependent and independent variables, respectively. 
$\left.x_{i, t}\right)$. Thus, (4) can be used to derive the long-run coefficients of the regressors $\left(\ln G D P_{i, t},\left(\ln G D P_{i, t}\right)^{2}, \ln F D I_{i, t}\right.$ and $\left.\ln P o p_{i, t}\right)$ which is given by (5) [42].

$$
\ln C O_{2 i, t}=-\left(e_{i}^{\prime} / d_{i}\right) \ln x_{i, t}+u_{i, t}
$$

Once long-run has been established, a Restricted Error Correction Model (RECM) can be used to investigate the short-run behavior of the variables, which is given by (6). This model takes the cointegration form of the simple ARDL model and adapts it for a panel setting by allowing the intercepts, short-run coefficients and cointegrating terms to differ across cross-sections. The RECM includes the lagged error correction term $\left(E C T_{t-1}\right)$ or the cointegrating term as an additional explanatory variable, and it indicates the speed of adjustment or how quickly the variables return from shortrun shocks to the long-run equilibrium. Its coefficient $f_{i}$ in (6) should have a negative sign and statistically significant in order for the PMG estimates to have meaningful interpretations.

Specifically, the RECM can be written as:

$$
\begin{aligned}
& \Delta \ln C O_{2 i, t}=a_{i}+\sum_{k=1}^{p-1} b_{i k} \Delta \ln C O_{2 i, t-k}+\sum_{k=0}^{q-1} c^{\prime}{ }_{i k} \Delta \ln x_{i, t-k}+ \\
& f_{i} E C T_{i, t-1}+u_{i, t}
\end{aligned}
$$

Note that it is assumed that both the dependent variable and regressors have the same number of lags in each crosssection. Moreover, for notational convenience, it is also assumed that all the regressors have the same number of lags $q$ in each cross-section.

\subsection{Causality Analysis}

The second major objective of the study is to examine whether $\mathrm{CO}_{2}$ emissions stimulate, retard, or are neutral to economic growth, by investigating the direction of causality between these variables. As stated above, the PMG method examines the existence or absence of a cointegrating relationship between variables, but not the direction of causality. Moreover, the Granger representation theorem suggests that there will be Granger causality in at least one direction, if there exist a long-run relationship among the variables in the UECM (4), but not vice versa [5].

Even though it may not hold in all circumstances, a unidirectional causal relationship, which runs from the change in the level of economic activity (per capita income) to the environmental quality, and not vice versa, is presumed by the EKC hypothesis. While this presumption appears reasonable, it is possible that a change in the level of economic activity to be a cause or the result of a change in the environmental quality. Moreover, there is a rising concern about whether environmental constraints limit development, or whether the ongoing process of development causes serious environmental damage $[1,43]$. Based on the assumptions made about the homogeneity of the coefficients across cross-sections, two forms of panel causality tests are proposed in the literature. The first is to treat the panel data as one large stacked set of data, and then perform the Granger Causality test in the standard way, with the exception of not letting data from one cross-section enter the lagged values of data from the next cross-section. This method assumes that all coefficients are same across all cross-sections. The second approach, which is followed in our study, makes an extreme opposite assumption, allowing all coefficients to be different across cross-sections [44]. Therefore, any possible causal relationship between the test variables can be examined by running the following least square bivariate regressions (7) and (8) in panel data context.

$$
\begin{aligned}
& y_{i, t}=a_{0, i}+a_{1, i} y_{i, t-1}+\ldots+a_{k, i} y_{i, t-k}+b_{1, i} x_{i, t-1}+\ldots+b_{k, i} x_{i, t-k}+\varepsilon_{i, t} \\
& x_{i, t}=a_{0, i}+a_{1, i} x_{i, t-1}+\ldots+a_{k, i} x_{i, t-k}+b_{1, i} y_{i, t-1}+\ldots+b_{k, i} y_{i, t-k}+\varepsilon_{i, t}
\end{aligned}
$$

Where $t$ denotes the time period dimension of the panel; and $i$ denotes the cross-sectional dimension; $y_{i, t}$ and $x_{i, t}$ denote any of the test variables of interest in country $i$ at time $t$, and $\varepsilon_{i, \mathrm{t}}$ 's are the serially uncorrelated error terms with mean zero and finite covariance matrix. Reference [44] has made the assumption, which allows all coefficients to be different across cross-sections, given by (9) and (10) as follows:

$$
\begin{gathered}
a_{0, i} \neq a_{0, j}, a_{1, i} \neq a_{1, j}, \ldots, a_{l, i} \neq a_{l, j}, \forall_{i, j} \\
b_{1, i} \neq b_{1, j}, \ldots, b_{l, i} \neq b_{l, j}, \forall_{i, j}
\end{gathered}
$$

\section{Data Source and Descriptive Analysis}

As to the source of the data, which are used for the study, annual panel data on GDP per capita in constant 2010 US\$, foreign direct investment (net inflows as percentage of GDP), total population, and $\mathrm{CO}_{2}$ emissions (metric tons per capita) for 12 East African countries ${ }^{2}$ for the period 1981-2016, are obtained from the World Bank's World Development Indicators [45]. Table 1 gives summary statistics of each of the variables used in the analysis.

Table 1. Descriptive statistics of the variables.

\begin{tabular}{llllll}
\hline & $\mathbf{C O}_{2}$ & GDP & GDP $^{2}$ & FDI & Pop \\
\hline Mean & -1.8536 & 6.5154 & 43.441 & -0.2157 & 15.633 \\
Median & -2.1861 & 6.2417 & 38.959 & -0.0281 & 16.142 \\
Maximum & 2.1901 & 9.4844 & 89.954 & 3.99013 & 18.368 \\
Minimum & -4.0584 & 5.0975 & 25.985 & -11.485 & 11.067 \\
Standard deviation & 1.3729 & 0.9970 & 14.557 & 2.19839 & 2.1064 \\
Skewness & 1.3414 & 1.5250 & 1.8256 & -1.6307 & -0.853 \\
Kurtosis & 4.5180 & 4.8500 & 5.6401 & 8.12463 & 2.5566 \\
Jarque-Bera & 123.92 & 165.96 & 264.78 & 481.222 & 40.522 \\
Probability & 0.0000 & 0.0000 & 0.0000 & 0.00000 & 0.0000 \\
Observations & 313 & 313 & 313 & 313 & 313 \\
\hline
\end{tabular}

Note: all variables are in their natural logarithmic (ln) forms

The mean value of $\operatorname{lnCO}_{2}$ emissions is -1.85 , and its range

2 Based on the UN's Economic Commission for Africa [46] these countries are: Burundi, Comoros, Congo Democratic Republic, Djibouti, Eritrea, Ethiopia, Kenya, Madagascar, Rwanda, Seychelles, Tanzania, and Uganda. However, Somalia and South Sudan, which are members of the East African block, are excluded from our study for the lack of data. 
is between -4.06 and 2.19 , with a standard deviation of 1.373 . Similarly, the mean values of $\ln G D P$ and $(\ln G D P)^{2}$ are 6.5154 and 43.442 , respectively. Furthermore, the value of the range of $\ln G D P$ is between 5.097 and 9.484 , and the range of $(\ln G D P)^{2}$ is between 25.985 and 89.954 , with their respective standard deviations of 0.997 and 14.557. Table 1 also shows that all the variables, except the natural logarithms of FDI and Pop, are positively skewed. In addition, all the variables have positive kurtosis with a value below 9 .

\section{Empirical Results and Discussions}

\subsection{Unit Root Test and Cointegration}

Generally, before proceeding to any econometric estimation of time-series or panel data set, it is natural to examine the order of integration or to carryout unit root test of the series using, which is very helpful in avoiding any spurious estimations [47-50]. The objective of the unit root test is to check whether the concerned variables are stationary at levels $I(0)$, or non-stationary at levels and become stationary after taking their first differences $I(1)$, and to prove that none of them are stationary at second difference I(2) and above. In all these tests, the null hypothesis that a series has a unit root is tested against its alternative of stationarity. Table 2 summarizes the outcome of unit root tests of the natural logarithms of the variables at levels and at their first differences. It shows that all the series, except FDI which is stationary at level, are non-stationary at their level forms, but become stationary after taking their first differences $I(1)$, indicating that none of the variables are $I(2)$ or beyond. This implies the possibility of cointegrating relationships, and hence validating the use PMG analysis.

Table 2. Unit root test results.

\begin{tabular}{|c|c|c|c|c|c|c|c|c|}
\hline \multicolumn{9}{|l|}{ At Level } \\
\hline \multirow{2}{*}{ Variable } & \multicolumn{2}{|c|}{ Levin, Lin \& Chu $t^{*}$} & \multicolumn{2}{|c|}{ Im, Pesaran and Shin W-stat } & \multicolumn{2}{|c|}{ ADF - Fisher Chi-square } & \multicolumn{2}{|c|}{ PP - Fisher Chi-square } \\
\hline & Statistic & P-Value & Statistic & P-Value & Statistic & P-Value & Statistic & P-Value \\
\hline $\mathrm{CO}_{2}$ & 0.4621 & 0.678 & 1.54064 & 0.9383 & 19.5674 & 0.7211 & 21.7508 & 0.5941 \\
\hline GDP & 1.4472 & 0.9261 & 3.43218 & 0.9997 & 11.6787 & 0.9833 & 14.6325 & 0.9311 \\
\hline $\mathrm{GDP}^{2}$ & 1.6808 & 0.9536 & 3.66511 & 0.9999 & 11.4919 & 0.985 & 14.4506 & 0.9358 \\
\hline Pop & -4.5816 & $0.00000^{* * *}$ & 1.26173 & 0.8965 & 34.6611 & 0.0736 & 64.3205 & 0.00000 \\
\hline FDI & -5.2907 & $0.00000^{* * *}$ & -4.90359 & $0.00000 * * *$ & 75.5692 & $0.00000 * * *$ & 124.488 & $0.00000 * * *$ \\
\hline \multicolumn{9}{|c|}{ At First Difference } \\
\hline \multirow{2}{*}{ Variable } & \multicolumn{2}{|c|}{ Levin, Lin \& Chu t* } & \multicolumn{2}{|c|}{ Im, Pesaran and Shin W-stat } & \multicolumn{2}{|c|}{ ADF - Fisher Chi-square } & \multicolumn{2}{|c|}{ PP - Fisher Chi-square } \\
\hline & Statistic & P-Value & Statistic & P-Value & Statistic & P-Value & Statistic & P-Value \\
\hline $\mathrm{D}\left(\mathrm{CO}_{2}\right)$ & -4.5404 & $0.00000 * * *$ & -7.5533 & $0.00000^{* * *}$ & 104.658 & $0.00000 * * *$ & 227.241 & $0.00000^{* * *}$ \\
\hline $\mathrm{D}(\mathrm{GDP})$ & -4.47661 & $0.00000^{* * *}$ & -6.62768 & $0.00000^{* * *}$ & 101.69 & $0.00000 * * *$ & 154.075 & $0.00000^{* * *}$ \\
\hline $\mathrm{D}(\mathrm{GDP})^{2}$ & -4.33508 & $0.00000^{* * *}$ & -6.43024 & $0.00000^{* * *}$ & 98.522 & $0.00000 * * *$ & 152.613 & $0.00000^{* * *}$ \\
\hline $\mathrm{D}$ (Pop) & -8.061 & $0.00000 * * *$ & -13.0971 & $0.00000 * * *$ & 204.506 & $0.00000 * * *$ & 52.4662 & $0.00000^{* * *}$ \\
\hline
\end{tabular}

Note: All variables are in their natural logarithmic $(\ln )$ forms. "D" represents the first difference operator; *** indicates statistical significance at 1 percent level

After confirming that all the variables are stationary, either at levels or in their first differences, we undertake Pedroni residual co-integration test to examine the presence of a long-run or cointegrating relationship among the variables [51]. The result of this test, which is given in table 3, shows that 6 out of the 11 test statistics are statistically significant either at 1 or 5 per cent levels of significance, which are enough to reject the null hypothesis of no cointegration.

Table 3. Pedroni residual based Cointegration test.

\begin{tabular}{|c|c|c|c|c|}
\hline \multicolumn{5}{|c|}{ Alternative hypothesis: common AR coefficients. (within-dimension) } \\
\hline & Statistic & Probability & Weighted Statistic & Probability \\
\hline Panel v-Statistic & 2.674102 & $0.0037 * * *$ & 2.125721 & $0.0168 * * *$ \\
\hline Panel rho-Statistic & -0.834686 & 0.2019 & -0.989547 & 0.1612 \\
\hline Panel PP-Statistic & -1.362195 & 0.0866 & -1.755790 & $0.0396 * *$ \\
\hline Panel ADF-Statistic & -2.099275 & $0.0179 * *$ & -2.020732 & $0.0217 * *$ \\
\hline
\end{tabular}

\begin{tabular}{lll}
\hline \multicolumn{2}{l}{ Alternative hypothesis: individual AR coefficients. (between-dimension) } & Probability \\
\hline Group rho-Statistic & Statistic & 0.5844 \\
Group PP-Statistic & 0.213171 & 0.0999 \\
Group ADF-Statistic & -1.282024 & $0.0161 * *$ \\
\hline
\end{tabular}

$* * *, * *$ indicates significance at 1 per cent and 5 per cent levels of significance, respectively. 


\subsection{Short-run Dynamics}

The presence of cointegrating relationship among the variables is a prerequisite for the estimation of a RECM, which is given in table 4 and can be used to determine the short-run dynamic behavior of the variables. The coefficient of the $E C T_{t-1}$, which represents for the speed of adjustment or convergence in a dynamic model following a sort-run shock, is negative and statistically significant at 5 per cent level of significance. This implies that the panel is nonexplosive and long-run equilibrium is attainable, which adds extra evidence for a stable long-run relationship between the regressors and $\mathrm{CO}_{2}$. This negative sign is what we would expect in our model, since there is a cointegrating relationship among the variables. The coefficient of the $E C T_{t-1}$ is -0.590865 . This implies that any deviation from the long-run equilibrium level of $\mathrm{CO}_{2}$ emissions in one year is corrected by nearly 59 per cent over the following year. Thus, it takes about two years to return to the long-run equilibrium level, following short-run shock. This indicates that the speed of adjustment is significantly fast in case of any shock.

In the short-term, the coefficient of the first difference of per capita GDP $D(\ln G D P)$ is positive and statistically significant at 10 per cent level of significance. However, the effect of per capita GDP squared $D(\ln G D P)^{2}$ is not significant. Therefore, we can say that the short-run relationship between $\mathrm{CO}_{2}$ emissions and per capita GDP is monotonically increasing, and the result of our study does not support the existence of an EKC in the short-run. Moreover, the effect of the first difference of FDI $D(\ln F D I)$ is negative and statistically significant at 10 per cent level of significance.

Table 4. Restricted error correction model (short-run equation).

\begin{tabular}{|c|c|c|c|c|}
\hline \multicolumn{5}{|c|}{ Dependent Variable: $\left.\mathrm{D}(\operatorname{lnCO})_{2}\right)$ Selected Model: $\operatorname{ARDL}(4,1,1,1,1)$} \\
\hline Variable & Coefficient & Standard Error & t-Statistic & Probability* \\
\hline $\mathrm{ECT}_{\mathrm{t}-1}$ & -0.590865 & 0.272792 & -2.165991 & $0.0315 * *$ \\
\hline $\mathrm{D}\left(\operatorname{lnCO} \mathrm{l}_{2(\mathrm{t}-1)}\right.$ & 0.183965 & 0.189762 & 0.969455 & 0.3335 \\
\hline $\mathrm{D}\left(\operatorname{lnCO}_{2(\mathrm{t}-2)}\right.$ & 0.155934 & 0.176460 & 0.883682 & 0.3779 \\
\hline $\mathrm{D}\left(\operatorname{lnCO}_{2(\mathrm{t}-3)}\right.$ & 0.134675 & 0.100873 & 1.335090 & 0.1834 \\
\hline $\mathrm{D}(\operatorname{lnGDP})$ & 31.35818 & 18.64191 & 1.682133 & $0.0941 *$ \\
\hline $\mathrm{D}(\operatorname{lnGDP})^{2}$ & -2.432059 & 1.479245 & -1.644122 & 0.1017 \\
\hline $\mathrm{D}(\ln \mathrm{FDI})$ & -0.018703 & 0.010323 & -1.811744 & $0.0715^{*}$ \\
\hline $\mathrm{D}(\ln$ Pop) & -8.167223 & 12.10445 & -0.674729 & 0.5006 \\
\hline Constant & -5.038548 & 2.645974 & -1.904232 & 0.0583 \\
\hline Log likelihood & & 364.0025 & & \\
\hline
\end{tabular}

Note: "D" represents for the first difference operator. ${ }^{* *}, *$ denote statistical significance at 5 and 10 percent levels, respectively.

\subsection{Long-run Relationship}

In addition to the short-run dynamic behavior of the variables, PMG can also be used to extract the long-run coefficients corresponding to (5). Table 5 presents the estimated long-run coefficients.

Table 5. Long-run coefficients.

\begin{tabular}{lllll}
\hline Dependent Variable: $\left(\mathbf{l n C O} \mathbf{O}_{2}\right)$ & & & \\
\hline Variable & Coefficient & Standard Error & t-Statistic & Probability* \\
\hline $\operatorname{lnGDP}$ & 1.013109 & 0.534929 & 1.893915 & $0.0597^{*}$ \\
$(\operatorname{lnGDP})^{2}$ & -0.040873 & 0.038364 & -1.065384 & 0.2880 \\
$\operatorname{lnFDI}$ & 0.010365 & 0.004500 & 2.303592 & $0.0223^{* *}$ \\
$\ln$ Pop & 0.135476 & 0.079885 & 1.695882 & $0.0915^{*}$ \\
\hline
\end{tabular}

Note: $* *, *$ denote statistical significant at 5 and 10 percent levels, respectively,

The result of our study shows that, the effect of per capita GDP is positive and statistically significant at 10 per cent level of significance. On the other hand, while the coefficient of per capita GDP squared has the expected negative sign, it has no statistically significant effect on $\mathrm{CO}_{2}$ emissions. This shows that $\mathrm{CO}_{2}$ emissions and per capita GDP, in East African countries, follows a monotonically increasing relationship, contrary to the inverted U-shaped relationship proposed by the EKC hypothesis. This implies that, overall, the growth of $\mathrm{CO}_{2}$ emissions in the region is still growing, and the East African region is in the early stage of development. Consequently, the EKC hypothesis cannot be confirmed for $\mathrm{CO}_{2}$ emissions, during 1981-2016 in East Africa. Moreover, the long-run coefficient of FDI is positive and statistically significant at 5 per cent level of significance. This shows that as net inflow of FDI as percentage of GDP increases, per capita $\mathrm{CO}_{2}$ emissions in kilotons also increases. Moreover, the coefficient of total population is positive and statistically significant at 10 per cent level of significance, indicating a direct relationship with $\mathrm{CO}_{2}$ emissions. In 
addition to this, since the model is a linear presented in a loglinear form, the coefficients represent elasticity of the dependent variable with respect to the independent variables. The long-run elasticity of per capita $\mathrm{CO}_{2}$ emissions with respect to income is given by 1.013109-0.040873( $\ln G D P)$; and the long-run elasticities of per capita $\mathrm{CO}_{2}$ emissions with respect to FDI and total population are given by 0.010365 and 0.135476 , respectively. Thus, the elasticity of $\mathrm{CO}_{2}$ emissions with respect to GPD per capita is the highest, followed by the elasticity of $\mathrm{CO}_{2}$ emissions with respect to total population and inflow of FDI, respectively.

\subsection{Short-run and Long-run Causalities}

Since the presence of the cointegrating relationship among the variables implies that causal relationship must exist at least from one direction; and since cointegration is a sufficient but not a necessary condition for Granger-causality, we next investigate the directions of the short-run and longrun Granger causalities between the variables. Because, examining the direction of causal relationship between economic growth and $\mathrm{CO}_{2}$ emissions is an important requirement in articulating comprehensive economic policies. Generally, before a RECM is estimated, there has to be an evidence of cointegration. Moreover, given the fact that cointegration implies a statistically significant lagged error correction term, the test for cointegration can be viewed as an indirect test for a long-run causality. The long-run causality is reported in the first row of table 6 , using the coefficient of the lagged error correction term in table 4, which is statistically significant at 5 percent level, using the t-test. This implies that in the long-run per capita GDP ( $G D P$ and $G D P^{2}$ ), FDI and total population Granger cause per capita $\mathrm{CO}_{2}$ emissions, or the causality runs interactively through the ECT from GDP, FDI and total population to per capita $\mathrm{CO}_{2}$ emissions.

Table 6. Results of Granger causality test.

\begin{tabular}{lllllll}
\hline & \multicolumn{1}{l}{$\mathbf{C O}_{2}$} & GDP & GDP $^{2}$ & FDI & Pop & ECT $_{\text {t-1 }}$ \\
\cline { 2 - 7 } & \multicolumn{2}{l}{ Short-run Granger causality W-Statistics } & Probability) & & t-statistics \\
\hline $\mathrm{CO}_{2}$ & -- & $10.714(0.00005)^{* * *}$ & $10.6415(0.00006)^{* * *}$ & $3.56966(0.0820)^{*}$ & $10.568(0.0000)^{* * *}$ & $-2.165991(0.0315)^{* *}$ \\
$\mathrm{GDP}$ & $3.91592(0.6019)$ & -- & $6.48989\left(0.0922^{*}\right)$ & $11.0051(0.00000)^{* * *}$ & $11.365(0.0000)^{* * *}$ & \\
$(\mathrm{GDP})^{2}$ & $3.94175(0.6140)$ & $6.45514(0.0981)^{*}$ & -- & $4.02809(0.0151)^{* *}$ & $11.4239(0.0000)^{* * *}$ & \\
$\mathrm{FDI}$ & $1.99594(0.7247)$ & $6.24158(0.0087)^{* * *}$ & $4.96482(0.0002)^{* * *}$ & -- & $9.34341(0.0000)^{* * *}$ & \\
Pop & $7.91541(0.0244)^{* *}$ & $15.2284(0.0000)^{* * *}$ & $14.9928(0.0000)^{* * *}$ & $4.48762(0.0024)^{* * *}$ & -- & \\
\hline
\end{tabular}

Notes: All the variables are in their natural logarithmic $(\ln )$ form. The null hypothesis is that there is homogenous non-causality between the variables (running from the column variable to the row variable); the $\mathrm{W}$ test statistic corresponds to the cross sectional average of the $\mathrm{N}$ standard individual Wald statistics of the Granger non-causality tests. ${ }^{* *}, * * * *$ indicate statistical significance at 1,5 and 10 per cent levels, respectively. The probability values are in brackets.

We have also investigated the short-run causal relationship between $\mathrm{CO}_{2}$ emission and the other variables included in the model. Table 6 present the results from Dumitrescu-Hurlin panel average Wald causality statistics and the associated probability values. It can be observed from the first row that the null hypotheses that GDP growth or FDI or Population do not homogeneously cause $\mathrm{CO}_{2}$ emission growth, are rejected. However, there is no reverse causality form $\mathrm{CO}_{2}$ emission to GDP or to FDI, implying that there are unidirectional shortrun causal relationships running from GDP and FDI to $\mathrm{CO}_{2}$ emissions. This result provides evidence that GDP has a predictive ability for $\mathrm{CO}_{2}$ emission. Moreover, there are bidirectional causal relationships running between total population and $\mathrm{CO}_{2}$ emissions, GDP and FDI, GDP and total population as well as total population and FDI. Therefore, the overall causality test provides strong evidence supporting for unidirectional causal relationship running from income to $\mathrm{CO}_{2}$ emissions in the short-run and the long-run, but not in the reverse direction. This implies that no feedback causal relationship that runs from $\mathrm{CO}_{2}$ emissions to income is observed in East Africa, both in the short and long-run. Thus, while economic growth causes more $\mathrm{CO}_{2}$ emissions, any effort to reduce $\mathrm{CO}_{2}$ emissions will not restrain growth of the economy in the region. As a result, emission reduction or abatement measures can be implemented to $\mathrm{CO}_{2}$ emissions and they are likely to have no adverse effect on the real output growth in East Africa.

\section{Conclusion and Recommendations}

Based on the EKC hypothesis, this study has investigated the long-run relationship between economic growth and $\mathrm{CO}_{2}$ emissions, during 1981-2016 in 12 East African countries. Accordingly, in addition to the GDP per capita, GDP per capita squared, foreign direct investment and total population are added to the model to determine their effects on the $\mathrm{CO}_{2}$ emissions. We have employed PMG technique to examine the long-run and short-run relationship between the variables. Contrary to what is hypothesized by the EKC hypothesis, the empirical result of our study reports a monotonically increasing relationship between per capita $\mathrm{CO}_{2}$ emissions and per capita GDP, both in the long-run and the short-run. Moreover, per capita $\mathrm{CO}_{2}$ emissions increases positively with respect to FDI and total population, in the long-run. The findings have important practical and policy implications. It calls for long-run environmental conservation policies that focus on promoting long-term investment in clean and renewable energy sources such as solar power, hydroelectricity, wind power, natural gas and adoption of new technologies and the modernization of the existing industries that reduce pollution. Moreover, countries must take several measures that decrease $\mathrm{CO}_{2}$ emission. These include, among several other measures, deployment of energy-efficient devices, carbontrading system, and imposition of a carbon tax on polluters, 
which would keep the economy green and preserve the environment for future generations. Further, since $\mathrm{CO}_{2}$ is not a local pollutant but a global one, perhaps creating regional cooperation between these countries to establish unified environmental acts would help to reduce $\mathrm{CO}_{2}$ emissions.

To complement the findings of our long-run and short-run relationships, and thus to examine the direction of causal relationships between the variables, we have performed short-run and long-run Granger causality using DumitrescuHurlin based causality test. The result of our study reports unidirectional causalities running from per capita GDP, FDI and total population to per capita $\mathrm{CO}_{2}$ emissions in the longrun, while unidirectional short-run causalities running from GDP and FDI to $\mathrm{CO}_{2}$ emissions and bidirectional causalities running between population and $\mathrm{CO}_{2}$ emissions. Therefore, any effort to reduce $\mathrm{CO}_{2}$ emissions will not restrain the development of the economy, as a result, emission reduction or abatement measures can be implemented to $\mathrm{CO}_{2}$ emissions and it is likely to have no adverse effect on the real output growth in East Africa.

\section{References}

[1] Teame, G. T. (2016). Economic growth and sulfur dioxide emissions in India: An empirical analysis. Rabindra Bharati University Journal of Economics, 10: 87-110.

[2] Managi, S., and Jena, P. R. (2007). Environmental productivity and Kuznets curve in India. Ecological $\begin{array}{lllll}\text { Economics, } & 6 & (2): & 432-440 . & \text { DOI: }\end{array}$ https://doi.org/10.1016/j.ecolecon.2007.07.011

[3] Bozkurt, C., and Akan, Y. (2014). Economic growth, $\mathrm{CO}_{2}$ emissions and energy consumption: The Turkish case. International Journal of Energy Economics and Policy, 4 (3): 484-494

[4] World Bank (2007). Growth and $\mathrm{CO}_{2}$ emissions: how do different countries fare. Environment Department, Washington, D. C. http://siteresources.worldbank.org/INTCC/2145741192124923600/21511758/CO2DecompositionfinalOct2007.pd f.

[5] Halicioglu, F. (2009). An econometric study of $\mathrm{CO}_{2}$ emissions energy consumption, income and foreign trade in Turkey. Energy Policy, 37 (3): 1156-1164.

[6] USAID. (2015). Greenhouse Gas Emissions in East Africa. https://www.climatelinks.org/resources/greenhouse-gasemissions-factsheet-east-africa

[7] Kuznets, S. (1955). Economic growth and income inequality. The American economic review, 1-28.

[8] Stern, D. I., Common, M. S., \& Barbier, E. B. (1996). Economic growth and environmental degradation: the environmental Kuznets curve and sustainable development. World development, 24 (7): 1151-1160.

[9] Marquart-Pyatt, S. (2004). A cross-national investigation of deforestation, debt, state fiscal capacity, and the environmental Kuznets curve. International Journal of Sociology, 34 (1): 33-51.

[10] Grossman, G. M., \& Krueger, A. B. (1991). Environmental impacts of a North American free trade agreement (No. w3914). National Bureau of Economic Research.

[11] Shafik, N., \& Bandyopadhyay, S. (1992). Economic growth and environmental quality: Time-series and cross-country evidence (Vol. 904). World Bank Publications.

[12] Panayotou, T. (1993). Empirical tests and policy analysis of environmental degradation at different stages of economic development (WEP 2-22/WP. 238). Geneva: International Labor Organization.

[13] Dinda, S. (2004). Environmental Kuznets curve hypothesis: A survey. Ecological economics, 49 (4): 431-455.

[14] Fodha, M., \& Zaghdoud, O. (2010). Economic growth and pollutant emissions in Tunisia: An empirical analysis of the environmental Kuznets curve. Energy Policy, 38 (2): 1150-1156.

[15] Selden, T. M., \& Song, D. (1994). Environmental quality and development: is there a Kuznets curve for air pollution emissions? Journal of Environmental Economics and management, 27 (2): 147-162.

[16] Armeanu, D., Vintilă, G., Andrei, J. V., Gherghina, S. C., Drăgoi, M. C., and Teodor, C. (2018). Exploring the link between environmental pollution and economic growth in EU28 countries: Is there an environmental Kuznets curve? PLoS ONE 13 (5), e0195708. DOI: 10.1371/journal.pone.0195708

[17] Cole, M. A., Rayner, A. J., \& Bates, J. M. (1997). The environmental Kuznets curve: An empirical analysis. Environment and development economics, 2 (4): 401-416.

[18] Shafik, N. (1994). Economic development and environmental quality: An econometric analysis. Oxford Economic Papers, 46: 757-773. DOI: 10.1093/oep/46.Supplement_1.757

[19] Kasman, A., \& Duman, Y. S. (2015). $\mathrm{CO}_{2}$ emissions, economic growth, energy consumption, trade and urbanization in new EU member and candidate countries: A panel data analysis. Economic Modelling, 44: 97-103. DOI: https://doi.org/10.1016/j.econmod.

[20] Charfeddine, L., \& Mrabet, Z. (2017). The impact of economic development and social-political factors on ecological footprint: A panel data analysis for 15 MENA countries. Renewable and Sustainable Energy Reviews, 76: 138-154. DOI: https://doi.org/10.1016/j.rser.2017.03.031

[21] Omri, A. (2013). $\mathrm{CO}_{2}$ emissions, energy consumption and economic growth nexus in MENA countries: Evidence from simultaneous equations models. Energy Economics, 40: 657664. DOI: http://dx.doi.org/10.1016/j.eneco.2013.09.003

[22] Arouri, M. H., Ben Youssef, A., M'henni, H., Rault, C. (2012). Energy consumption, economic growth and $\mathrm{CO}_{2}$ emissions in Middle East and North African countries. Energy Policy, 45: 342-349.

[23] Al-mulali, U., Tang, C. F., \& Ozturk, I. (2015). Estimating the environment Kuznets Curve hypothesis: Evidence from Latin America and the Caribbean countries. Renewable and Sustainable Energy Reviews, 50: 918-924. DOI: https://doi.org/10.1016/j.rser.2015.05.017

[24] Saboori, B., and Sulaiman, J. (2013). $\mathrm{CO}_{2}$ emissions, energy consumption and economic growth in Association of Southeast Asian Nations (ASEAN) countries: A cointegration approach. Energy, 55: 813-822. DOI: http://dx.doi.org/10.1016/j.energy.2013.04.038 
[25] Heidari, H., Turan Katircioğlu, S., \& Saeidpour, L. (2015). Economic growth, $\mathrm{CO}_{2}$ emissions, and energy consumption in the five ASEAN countries. International Journal of Electrical Power \& Energy Systems, 64: 785-791. DOI: https://doi.org/10.1016/j.ijepes.2014.07.081

[26] Lean, H. H., Smyth, R. (2010). $\mathrm{CO}_{2}$ emissions, electricity consumption and output in ASEAN. Applied Energy, 87: $1858-1864$

[27] Torras, M., \& Boyce, J. K. (1998). Income, inequality, and pollution: a reassessment of the environmental Kuznets curve. Ecological economics, 25 (2): 147-160.

[28] Cole, M. A., \& Elliott, R. J. (2003). Determining the tradeenvironment composition effect: The role of capital, labor and environmental regulations. Journal of Environmental Economics and Management, 46 (3): 363-383.

[29] Brajer, V., Mead, R. W., \& Xiao, F. (2008). Health benefits of tunneling through the Chinese environmental Kuznets curve (EKC). Ecological Economics, 66 (4): 674-686.

[30] Akbostanci, E., Türüt-Aşık, S., \& Tunç, G. İ. (2009). The relationship between income and environment in Turkey: Is there an environmental Kuznets curve? Energy Policy, 37 (3): 861-867.

[31] Aslanidis, N., \& Iranzo, S. (2009). Environment and development: Is there a Kuznets curve for $\mathrm{CO}_{2}$ emissions? Applied Economics, 41: 803-810. DOI: $10.1080 / 00036840601018994$

[32] Ahmed, K., Rehman, M. U., \& Ozturk, I. (2017). What drives carbon dioxide emissions in the long-run? Evidence from selected South Asian Countries. Renewable and Sustainable Energy Reviews, 70: 1142-1153. DOI: https://doi.org/10.1016/j.rser.2016.12.018

[33] Holtz-Eakin, D., Selden, T. M. (1995). Stoking the fires? $\mathrm{CO}_{2}$ emissions and economic growth. Journal of Public Economics, $57,85-101$

[34] Taguch, H. (2012). The environmental Kuznets curve in Asia: The case of sulphur and carbon emissions. Asia-Pacific $\begin{array}{llll}\text { Development Journal } 19 & \text { (2): 77-92. DOI: }\end{array}$ $10.18356 / 9 \mathrm{eb} 232 \mathrm{aa}-\mathrm{en}$

[35] Richmond, A. K., Kaufmann, R. K. (2006). Is there a turning point in the relationship between income and energy use and/or carbon emissions? Ecological Economics, 56: 176-189.

[36] Salahuddin, M., Gow, J., \& Ozturk, I. (2015). Is the long-run relationship between economic growth, electricity consumption, carbon dioxide emissions and financial development in Gulf Cooperation Council Countries robust? Renewable and Sustainable Energy Reviews, 51: 317-326. DOI: 10.1016/j.rser.2015.06.005

[37] Kais, S., \& Ben Mbarek, M. (2017). Dynamic relationship between $\mathrm{CO}_{2}$ emissions, energy consumption and economic growth in three North African countries. International Journal of Sustainable Energy, 36: 840-854. DOI: $10.1080 / 14786451.2015 .1102910$
[38] Farhani, S., \& Rejeb, J. (2012). Link between economic growth and energy consumption in over 90 countries. Interdisciplinary Journal of Contemporary Research in Business, 3: 199-210.

[39] Sisay Demissew Beyene \& Balázs Kotosz (2019). Testing the environmental Kuznets curve hypothesis: an empirical study for East African countries. International Journal of Environmental Studies. 10.1080/00207233.2019.1695445

[40] Goodness C. Aye \& Prosper Ebruvwiyo Edoja (2017). Effect of economic growth on $\mathrm{CO}_{2}$ emission in developing countries: Evidence from a dynamic panel threshold model, Cogent Economics \& Finance, 5 (1): 1379239. DOI: $10.1080 / 23322039.2017 .1379239$

[41] Lieb, C. M. (2004). The environmental Kuznets curve and flow versus stock pollution: The neglect of future damages. Environmental and resource economics, 29 (4): 483-506.

[42] Pesaran, M. H., Shin, Y., and Smith, R. J. (1999). Pooled mean group estimation of dynamic heterogeneous panels. Journal of the American Statistical Association, 94 (446): 621-634. DOI: $10.1080 / 01621459.1999 .10474156$

[43] S. Dinda. Environment and development trajectory: A fresh look on theory and empirics. New York: Nova Science Publishers, Inc. 2009.

[44] Dumitrescu, E. I., \& Hurlin, C. (2012). Testing for Granger noncausality in heterogeneous panels. Economic Modelling, 29: $1450-1460 . \quad$ DOI: https://doi.org/10.1016/j.econmod.2012.02.014

[45] World Bank (2017). World Development Indicators 2017. Washington, DC: World Bank. Retrieved from http://data.worldbank.org/data-catalog/world-developmentindicators.

[46] United Nations-Economic Commission for Africa. (2019). Macroeconomic and Social Development in Eastern Africa2019: Benchmarking performance towards national, regional and international goals. Available at: www.unaca.com

[47] Levin, A., Lin, C. F., and Chu, C. S. J. (2002). Unit root tests in panel data: Asymptotic and finite-sample properties. Journal of Econometrics, 108 (1): 1-24. DOI: 10.1016/S03044076(01)00098-7

[48] Im, K. S., Pesaran, M. H., and Shin, Y. (2003). Testing for unit roots in heterogeneous panels. Journal of Econometrics, 115 (1): 53-74. DOI: 10.1016/S0304-4076(03)00092-7

[49] Dickey, D. A. and Fuller, W. A. (1979). Distribution of the estimators for autoregressive time series with a unit root. Journal of the American Statistical Association, 74: 427- 431.

[50] Phillips, P. C. B. and Perron, P. (1988). Testing for a unit root in time series regression. Biometrika, 75: 335-346.

[51] Pedroni, P. (2004). Panel cointegration: Asymptotic and finite sample properties of pooled time series tests with an application to the PPP hypothesis. Econometric Theory, 20 (3): 597-625. DOI: 10.1017/S0266466604203073 